\title{
FACTORS RELATED TO FALLING RISK PREVENTION OF PATIENTS AT RSUD ENCIK MARIYAM DAIK LINGGA IN 2020
}

\author{
Zurva Ramayana ${ }^{1}$ \\ ${ }^{1}$ Program Studi IImu Keperawatan STIKes Awal Bros Batam
}

Email korespondensi: zulfa.rohmah74@gmail.com

\begin{abstract}
The patient's risk of falling is an increased susceptibility to falls that can cause physical harm. Prevention of falling patients is carried out by means of assessment, the use of a yellow bracelet for a high fall risk; as well as conducting regular monitoring and evaluation. External factors that influence the implementation of fall risk prevention are organizational and management factors, work environment, team factors, staff factors, task factors, patient factors, and communication factors. Monitoring results obtained by nurses have provided fall prevention education, there are still bedrails that are not raised and there are high risk patients. From these data it can be concluded that the nurse has carried out the fall risk assessment properly but the implementation of fall prevention has not been optimal and there is a risk of falling patients. The purpose of this study was to determine the factors related to the risk of falling patients by nurses at Encik Mariyam Daik Lingga Hospital in 2019. This study used a descriptive analytical method with a cross sectional approach, the sample selection was carried out by using total sampling technique, the number of samples used was 32 respondents. The results were analyzed by using the chi square test and showed a relationship between factors, namely knowledge, attitudes and motivation of nurses with preventive measures for the risk of falling patients by nurses at RSUDEncik Mariyam Daik Lingga in 2019. Researcher's suggestions are that nurses can further improve knowledge, attitudes and motivation for good performance. especially in providing nursing care in the form of prevention of the risk of falling patients.
\end{abstract}

\section{Keywords : Attitudes, Implementation, Knowledge, Motivation}

\section{PENDAHULUAN}

Kejadian pasien jatuh merupakan masalah serius di rumah sakit terutama pasien rawat inap karena kejadian pasien jatuh merupakan salah satu indikator keselamatan pasien dan indikator mutu rumah sakit. "Risiko jatuh pasienadalah peningkatan kerentanan terhadap jatuh yang dapat menyebabkan bahaya fisik" (Wilkinson, 2015). "Pasien jatuh di rumah sakit merupakan masalah yang serius karena dapat menyebabkan cedera ringan sampai 
dengan kematian, serta juga dapat memperpanjang lama hari rawat (Length of Stay/LOS) di rumah sakit dan akan menambah biaya perawatandi rumah sakit" (Joint Commission Internasional, 2015). "Penyebab terjadinya resiko jatuh bisa disebabkan oleh faktor intrinsik berupa riwayat jatuh sebelumnya, penurunan ketajaman penglihatan, prilaku dan sikap berjalan, sistem muskuloskeletal, status mental, penyakit akut, dn penyakit kronik. Dari segi faktor ekstrinsik bisa berupa pengobatan, kamar mandi, desain bangunan, kondisi permukaan lantai, kurang pencahayaan" (JCI, 2015). "Ada beberapa faktor yang mempengaruhi terjadinya resiko jatuh yaitu: faktor eksternal, faktor organisasi \& manajemen, faktor lingkungan kerja, faktor tim, faktor petugas, faktor tugas, faktor pasien, dan faktor komunikasi” (Kemenkes, 2015).

Faktor-faktor yang mempengaruhi penerapan keselamatan pasienmenurut Lawrence Green dalam Notoatmodjo (2014) menyatakan bahwa "ada tiga faktor yang mempengaruhi perilaku kerja dan kinerja seseorang dalam penerapan keselamatan pasien, yaitu: faktor predisposisi (prediposing factors) yaitu sikap dan pengetahuan perawat, faktor pemungkin (enabling factor) yaitu SDM, Kepemimpinan, imbalan, struktur organisasi, desain pekerjaan, dan faktor pendorong (reinforcing factor)yaitu pelatihan dan motivasi”.

Gambaran kejadian pasien jatuh dari data komite mutu rumah sakit dan hasil wawancara dengan tim K3RSdi RSUD Encik Mariyamdidapatkan datapada tahun 2018 untuk triwulan I (Januari-Maret), triwulan II (April-Juni) dan triwulan III (Juli-September) angka kejadian pasien jatuh sebesar 4 kejadian. Dimana kejadian pada triwulan I sebesar 3 kejadian dan triwulan II sebesar 1 kejadian. Kejadian jatuh tersebut tidak mengakibatakan cedera berat atau kematian tetapi kejadian tersebut merupakan insiden keselamatan pasien yaitu kejadian tidak cedera dan kejadian tidak diharapkan.

Penelitian ini bertujuan untuk mengetahui Faktor Faktor Yang Berhubungan Dengan Tindakan Pencegahan Resiko Jatuh Pasien Oleh Perawat Di RSUDEncik Mariyam Daik LinggaTahun 2020. 


\section{METODE}

Jenis penelitian yag digunakan adalah "deskriptif korelasional dan pendekatan adalah cross sectional yaitu jenis penelitian yang menekankan pada suatu pengukuran/ observasi data variabel independen dan dependen hanya satukali, pada satu saat" (Nursalam, 2014), dimana peneliti mencoba menggali bagaimana Faktor Faktor Yang Berhubungan Dengan Tindakan Pencegahan Resiko Jatuh Pasien Oleh Perawat Di RSUD Encik Mariyam Daik Lingga Tahun 2019 (Nursalam, 2014). Pemilihan sampel dilakukan dengan tekhik Total sampling, jumlah sampel yang digunakan sebanyak 32responden. Alat pengumpulan data berupa kuesioner yang dibagikan terhadap responden. Hasil penelitian dianalisa dengan uji chi square.

\section{HASIL}

Tabel 1 Distribusi Frekuensi Karakteristik Responden Perawat Di RSUD Encik Mariyam Daik LinggaTahun 2020

\begin{tabular}{|c|c|c|c|}
\hline No & Karaktaresktik & Jumlah (f) & Persentase (\%) \\
\hline \multirow[t]{4}{*}{1} & Usia & & \\
\hline & Dewasa awal (20-30 tahun) & 11 & 34,4 \\
\hline & Dewasa tengah ( $>30-65$ tahun) & 21 & 65,6 \\
\hline & Total & 32 & 100 \\
\hline \multirow[t]{4}{*}{2} & Jenis Kelamin & & \\
\hline & Perempuan & 24 & 75,0 \\
\hline & Laki-laki & 8 & 25,0 \\
\hline & Total & 32 & 100 \\
\hline \multirow[t]{4}{*}{3} & Masa kerja & & \\
\hline & $1-5$ tahun & 12 & 37,5 \\
\hline & $6-10$ tahun & 20 & 62,5 \\
\hline & Total & 32 & 100 \\
\hline \multirow[t]{4}{*}{4} & Pendidikan & & \\
\hline & D3 & 30 & 93,7 \\
\hline & S1 & 2 & 6,3 \\
\hline & $\overline{\text { Total }}$ & 32 & 100 \\
\hline
\end{tabular}

Tabel 1 diketahui bahwa karakteristik responden berdasarkan usia dikelompokkan menjadi 2 kelompok yaitu dewasa awal (20-30 tahun) sebanyak 11 orang $(34,4 \%)$ dan dewasa tengah (> 30-65) sebanyak 21 orang $(65,6 \%)$. Karakteristik responden berdasrkan jenis kelamin yaitu perempuan sebanyak 24 
orang $(75 \%)$ dan laki laki 8 orang (25\%). Karakteristik responden berdasarkan masa kerja yaitu 1-5 tahun sebanyak 12 orang ( $37,5 \%$ ) dan masa kerja $6-10$ tahun sebanyak 20 orang ( $62,5 \%$ ). Karakteristik responden berdasarkan pendidikan terakhir yakni sebagian besar responden dengan pendidikan terakhir D3 yaitu sebanyak 30 orang $(93,7 \%)$, dan S1 yaitu sebanyak 2 orang $(6,3 \%)$.

Tabel 2 Distribusi Frekwensi Pengetahuan Perawat Di RSUD Encik Mariyam Daik Lingga Tahun 2020

\begin{tabular}{lcc}
\hline \multicolumn{1}{c}{ Pengetahuan } & $\mathrm{f}$ & $\%$ \\
\hline Pengetahuan tinggi & 5 & 15,6 \\
Pengetahuan sedang & 16 & 50,0 \\
Pengetahuan rendah & 11 & 34,4 \\
\hline \multicolumn{1}{c}{ Total } & $\mathbf{3 2}$ & $\mathbf{1 0 0}$ \\
\hline
\end{tabular}

Tabel 2 didapat hasil bahwa responden dengan kriteria pengetahuan tinggi sebanyak 5 orang $(15,6 \%)$ pengetahuan sedang sebanyak 16 orang $(50,0 \%)$ dan pengetahuan rendah sebanyak 11 orang $(34,4 \%)$.

Tabel 3 Distribusi frekuensi sikap Perawat Di RSUD Encik Mariyam Daik Lingga Tahun 2020

\begin{tabular}{|c|c|c|}
\hline Sikap Responden & $\mathbf{f}$ & $\%$ \\
\hline Sikap positif & 21 & 65,6 \\
\hline Sikap Negatif & 11 & 34,4 \\
\hline Total & 32 & 100 \\
\hline
\end{tabular}

Tabel 3 diatas, distribusi frekuensi berdasarkan sikap responden yaitu sikap positif sebanyak 21 orang $(65,6 \%)$, dan sikap negatif sebanyak 11 orang $(34,4 \%)$.

Tabel 4. Distribusi frekuensi motivasi Perawat Di RSUD Encik Mariyam Daik Lingga Tahun 2020

\begin{tabular}{|c|c|c|}
\hline Motivasi Responden & f & $\%$ \\
\hline Baik & 17 & 53,1 \\
\hline Kurang & 15 & 46,9 \\
\hline Total & 32 & 100 \\
\hline
\end{tabular}

Tabel 4 diatas distribusi frekuensi berdasarkan motivasi responden yaitu motivasi baik sebanyak 17 orang $(53,1 \%)$ dan motivasi kurang sebanyak 15 orang $(46,9 \%)$. 
Tabel 5. Distribusi frekuensi pelaksanaan Tindakan Pencegahan Resiko Jatuh Pasien oleh Perawat Di RSUD Encik Mariyam Daik Lingga Tahun 2020

\begin{tabular}{lcc}
\hline $\begin{array}{l}\text { Pelaksaan tindakan pencegahan } \\
\text { resiko jatuh }\end{array}$ & f & \% \\
\hline Dilakukan & 21 & 65,6 \\
Tidak dilakukan & 11 & 34,4 \\
\hline \multicolumn{1}{c}{ Total } & $\mathbf{3 2}$ & $\mathbf{1 0 0}$ \\
\hline
\end{tabular}

Tabel 5 diperoleh hasil bahwa Distribusi frekuensi pelaksanaan Tindakan Pencegahan Resiko Jatuh Pasien oleh responden dengan kriteria dilakukan sebanyak 21 orang $(65,6 \%)$ dan tidak dilakukan sebanyak 11 orang $(34,4 \%)$.

\section{Analisa Bivariat}

Tabel 6. Analisa Hubungan pengetahuan dengan pelaksanaan Tindakan Pencegahan Resiko Jatuh Pasien Di RSUD Encik Mariyam Daik Lingga Tahun 2020

\begin{tabular}{|c|c|c|c|c|c|c|c|}
\hline \multirow{3}{*}{ Pengetahuan } & \multicolumn{4}{|c|}{ Pelaksanaan resiko jatuh } & \multirow{3}{*}{ Total } & \multirow{3}{*}{$\begin{array}{c}\text { Jumlah } \\
\%\end{array}$} & \multirow{3}{*}{$p$} \\
\hline & \multicolumn{2}{|c|}{ Tidak dilaksanakan } & \multicolumn{2}{|c|}{ Dilaksanakan } & & & \\
\hline & $\mathrm{f}$ & $\%$ & $\mathrm{f}$ & $\%$ & & & \\
\hline Rendah & 10 & 31,3 & 1 & 3,1 & 11 & 34,4 & \\
\hline Sedang & 1 & 3,1 & 15 & 46,9 & 16 & 50 & 0000 \\
\hline Tinggi & 0 & 0 & 5 & 15,6 & 5 & 15,6 & 0,000 \\
\hline Total & 11 & 34,4 & 21 & 65,6 & 32 & $100 \%$ & \\
\hline
\end{tabular}

Tabel 6 diperoleh hasil analisa bahwa responden dengan pengetahuan rendah sebanyak 11 orang $(34,4 \%)$ dengan pelaksanaan resiko jatuh dengan kriteria tidak dilaksanakan sebanyak 10 orang (31,3\%) dan dilaksanakan sebanyak 1 orang $(3,1 \%)$, responden dengan pengetahuan sedang sebanyak 16 orang $(50 \%)$ dengan pelaksanaan resiko jatuh dengan kriteria tidak dilaksanakan sebanyak 1 orang $(3,1 \%)$ dan dilaksanakan sebanyak 15 orang $(46,9 \%)$, dan responden dengan pengetahuan tinggi sebanyak 5 orang $(15,6 \%)$ dengan pelaksanaan resiko jatuh dengan kriteria tidak dilaksanakan sebanyak 0 orang $(0$ $\%$ ) dan dilaksanakan sebanyak 5 orang $(15,6 \%)$. Berdasarkan hasil uji Chi square di dapatkan hasil $\mathrm{p}$ value 0,000 , terdapat hubungan antara pengetahuan responden dengan pelaksanaan Tindakan Pencegahan Resiko Jatuh Pasien.

Tabel 7. Analisa Hubungan Sikap dengan pelaksanaan Tindakan Pencegahan Resiko Jatuh Pasien Di RSUD Encik Mariyam Daik Lingga Tahun 2020 


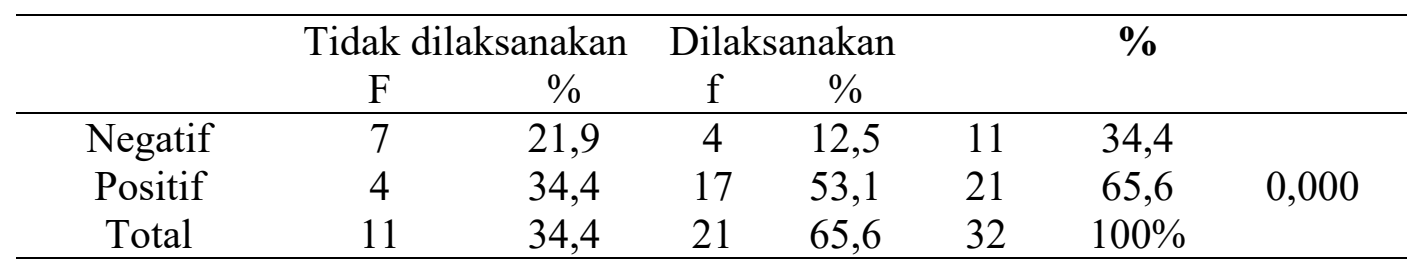

Tabel 7 diperoleh hasil analisa bahwa responden dengan sikap negatif sebanyak 11 orang $(34,4 \%)$ dengan pelaksanaan resiko jatuh dengan kriteria tidak dilaksanakan sebanyak 7 orang $(21,9 \%)$ dan dilaksanakan sebanyak 4 orang $(12,5 \%)$ dan responden dengan sikap positif sebanyak 21 orang $(65,6 \%)$ dengan pelaksanaan resiko jatuh dengan kriteria tidak dilaksanakan sebanyak 4 orang $(12,5 \%)$ dan dilaksanakan sebanyak 17 orang $(53,1 \%)$. Berdasarkan hasil uji Chi square di dapatkan hasil $\mathrm{p}$ value 0,012, terdapat hubungan antara Sikap responden dengan pelaksanaan Tindakan Pencegahan Resiko Jatuh Pasien.

Tabel 8. Analisa Hubungan Motivasi dengan pelaksanaan Tindakan Pencegahan Resiko Jatuh Pasien Di RSUD Encik Mariyam Daik Lingga Tahun 2020

\begin{tabular}{cccccccc}
\hline \multirow{2}{*}{ Motivasi } & \multicolumn{3}{c}{ Pelaksanaan resiko jatuh } & \multicolumn{3}{c}{ Jumlah } & \multirow{2}{*}{$p$} \\
\cline { 2 - 5 } & \multicolumn{2}{c}{ Tidak dilaksanakan } & \multicolumn{2}{c}{ Dilaksanakan } & Total & \% & \\
& $\mathrm{F}$ & $\%$ & $\mathrm{f}$ & $\%$ & & & \\
& 9 & 28,1 & 6 & 18,8 & 15 & 46,9 & \multirow{2}{*}{0,000} \\
Kurang & 2 & 6,3 & 15 & 46,9 & 17 & 53,1 & \\
Baik & 11 & 34,4 & 21 & 65,6 & 32 & $100 \%$ & \\
Total & & & & &
\end{tabular}

Tabel 8 diperoleh hasil analisa bahwa responden dengan motivasi kurang sebanyak 15 orang $(46,9 \%)$ dengan pelaksanaan resiko jatuh dengan kriteria tidak dilaksanakan sebanyak 9 orang $(28,1 \%)$ dan dilaksanakan sebanyak 6 orang $(18,8 \%)$ dan responden dengan motivasi baik sebanyak 17 orang $(53,1 \%)$ dengan pelaksanaan resiko jatuh dengan kriteria tidak dilaksanakan sebanyak 2 orang $(6,3 \%)$ dan dilaksanakan sebanyak 15 orang (4 6,9\%). Berdasarkan hasil uji Chi square di dapatkan hasil $\mathrm{p}$ value 0,004 , terdapat hubungan antara motivasi responden dengan pelaksanaan Tindakan Pencegahan Resiko Jatuh Pasien.

\section{PEMBAHASAN}

\section{Analisa Univariat}

\section{a. Distribusi frekuensi berdasarkan pengetahuan responden}

Hasil penelitian diketahui bahwa responden dengan kriteria pengetahuan tinggi sebanyak 5 orang $(15,6 \%)$ pengetahuan sedang sebanyak 16 orang $(50,0 \%)$ dan 
pengetahuan rendah sebanyak 11 orang (34,4\%). "Pengetahuan, kemampuan, keterampilan, dan kepribadian merupakan bagian dari karakteristik individual yang akan mempengaruhi perilaku organisasi. Sumber daya manusia bidang kesehatan termasuk perawat merupakan hal yang berhubungan dengan komimen yang sangat diperlukan dalam upaya untuk membangun budaya keselamatan pasien" (Cahyono,2008).

Penelitian yang dilakukan oleh Ayu Maulida menyatakan bahwa "pengetahuan yang dimiliki perawatada hubungan yang signifikandengan pencegahan risiko pasien jatuh. Dalam penelit sangat jelas bahwa pengetahuan tinggi tanpa didasari perilaku sikap yang baik maka pencegahan pasien risiko jatuh tidak akan terlaksana dengan baik. Peneliti berasumsi bahwa pengetahuan responden yaitu perawat di RSUD Encik Mariyam, Daik Lingga tergolong baik sesuai dengan hasil yang diperoleh yaituresponden dengan kriteria pengetahuan tinggi sebanyak 5 orang $(15,6 \%)$ pengetahuan sedang sebanyak 16 orang $(50,0 \%)$ dan pengetahuan rendah sebanyak 11 orang (34,4\%). Peneliti menyimpulkan bahwa pengetahuan responden yang baik akan berdampak baik juga dalam pemberian pelayanan terhadap pasien terutama dalam pelaksanaan pencegahan resiko jatuh".

\section{b. Distribusi frekuensi berdasarkan sikap responden}

Dari penelitian diperoleh hasil bahwadistribusi frekuensi berdasarkan sikap responden yaitu sikap positif sebanyak 21 orang $(65,6 \%)$, dan sikap negatif sebanyak 11 orang(34,4\%). Penelitian Lombogia, dkk (2016) yangmenyatakan bahwa terdapat hubung anantara perilaku dengan kemampuan perawat dalam melaksanakan patient safety di Ruang Akut RSUP Prof.Dr.D.R.Kandou Manado, pada resiko pasien jatuh mempunyai nilai $p$ value 0.001. Peneliti berasumsi bahwa sikap perawat di RSUS Encik Mariyam Daik Lingga cukup baik dimana perolehan hasil penelitian yaitu distribusi frekuensi berdasarka sikap responden yaitu sikap positif sebanyak 21 orang $(65,6 \%)$, dan sikap negatif sebanyak 11 orang $(34,4 \%)$.Sikap positif yang diberikan perawat sangat berdampak baik terhadap kualitas pelayanan pasien 
terutama dalam pelaksanaan pencegahan resiko jatuh pasien. Sikap positif ini perluterus ditingkatkan, dan perlu adanya reward guna mendukung terciptanya sikap yang positif tersebut.

\section{c. Distribusi frekuensi berdasarkan motivasi responden}

Berdasarkan perolehan hasil penelitian yaitu distribusi frekuensi berdasarkan motivasi responden yaitu motivasi baik sebanyak 17 orang $(53,1 \%)$ dan motivasi kurang sebanyak 15 orang (46,9\%). Penelitian yang dilakukan Handayani, Ariani, dan Maemunah (2017) mengenai motivasi perawat dengan pelaksanaan Standar Prosedur Operasional (SPO) assesmen nyeri ulang di ruang rawat inap dewasa rumah sakit Panti Waluya Sawahan Malang menunjukan bahwa hampir seluruh perawat mempunyai motivasi yang baik dalam melaksanakan SPO assesmennyeri ulang, dan hanya sebagian kecil yang mempunyai motivasi kurang. Peneliti berasumsi bahwa motivasi perawat di RSUD Encik Mariyam Daik Lingga tergolong baik dengan perolehan hasil penelitian yaitu distribusi frekuensi berdasarkan motivasi responden yaitu motivasi baik sebanyak 17 orang $(53,1 \%)$ dan motivasi kurang sebanyak 15 orang (46,9\%). Peneliti menyimpulkan bahwa "motivasi perawat ini di pengaruhi oleh factor factor instrinstik dan ekstrinsik. Faktor intrinsik muncul dalam diri yang dapat membangkitkan motivasi perawat, sebagai contoh kesadaran diri perawat dalam melaksanakan assesmenrisiko jatuh. Sedangkan motivasi ekstrinsik berkaitan dengan faktor di luar individu seperti hubungan antar rekan kerja, hubungan dengan atasan, serta reward dan punishment" (Markuis \& Huston, 2010).

\section{d. Distribusi frekuensi berdasarkan pelaksanaanTindakan Pencegahan Resiko Jatuh Pasien oleh responden}

Distribusi frekuensi pelaksanaan Tindakan Pencegahan Resiko Jatuh Pasien oleh responden dengan kriteria dilakukan sebanyak 21 orang $(65,6 \%)$ dan tidak dilakukan sebanyak 11 orang $(34,4 \%)$. Pencegahan pasien jatuh dapat dilakukan dimulai dari: melakukan assesmen awal pasien masuk untuk 
dirawat, dan assesmen lanjut apabila terdapat perubahan kondisi pada pasiendengan mengunakan Scale untuk pasien dewasa dan Humpty Dumpty Scale anak-anak; menerapkan langkah langkah untuk mengurangi jatuh dengan menetapkan kebijakan dan memasang gelang khusus penanda pasien merupakan pasien jatuh tinggi; memonitor dan mengevaluasiberkala terhadap keberhasilan pengurangan cidera akibat dampak terkait lainnya menggunakan form; serta membuat Standar Operasional Prosedur dan prosedur mendukung pengurangan berkelanjutan dari risiko cidera pasien jatuh di rumah sakit.Penulis berasumsi bahwa pelaksanaan pencegahan resiko jatuh di RSUD Encik Mariyam Daik Lingga cukup baik, hal ini dibuktikan dengan perolehan hasil penelitian yaitu distribusi frekuensi pelaksanaan Tindakan Pencegahan Resiko Jatuh Pasien oleh responden dengan kriteria dilakukan sebanyak 21 orang $(65,6 \%)$ dan tidak dilakukan sebanyak 11 orang $(34,4 \%)$. Pelaksanaan pencegahan resiko jatuh yang baik ini tidak lepas dari faktur factor pendukung yaitu pengetahuan, sikap dan motivasi responden yang baik.

\section{Analisa Bivariat}

\section{a. Hubungan pengetahuan dengan pelaksanaan Tindakan Pencegahan}

\section{Resiko Jatuh Pasien}

Berdasarkan hasil penelitian diperoleh hasil analisa bahwa responden dengan pengetahuan rendah sebanyak 11 orang (34,4\%) dengan pelaksanaan resiko jatuhdengan kriteria tidak dilaksanakan sebanyak 10 orang $(31,3 \%)$ dan dilaksanakan sebanyak 1 orang $(3,1 \%)$, responden dengan pengetahuan sedang sebanyak 16 orang (50\%) dengan pelaksanaan resiko jatuh dengan kriteria tidak dilaksanakan sebanyak 1 orang $(3,1 \%)$ dan dilaksanakan sebanyak 15 orang $(46,9 \%)$, dan responden dengan pengetahuan tinggi sebanyak 5 orang $(15,6 \%)$ dengan pelaksanaan resiko jatuh dengan kriteria tidak dilaksanakan sebanyak 0 orang $(0 \%)$ dan dilaksanakan sebanyak 5 orang $(15,6 \%)$. Berdasarkan hasil uji Chi square di dapatkan hasil $\mathrm{p}$ value 0,000 , terdapat 
hubungan antara pengetahuan responden dengan pelaksanaan Tindakan Pencegahan Resiko Jatuh Pasien.

\section{b. Hubungan sikap dengan pelaksanaan Tindakan Pencegahan Resiko Jatuh Pasien}

Berdasarkan penelitian diperoleh hasil analisa bahwa responden dengan sikap negatif sebanyak 11 orang $(34,4 \%)$ dengan pelaksanaan resiko jatuh dengan kriteria tidak dilaksanakan sebanyak 7 orang $(21,9 \%)$ dan dilaksanakan sebanyak 4 orang $(12,5 \%)$ dan responden dengan sikap positif sebanyak 21 orang (65,6\%) dengan pelaksanaan resiko jatuh dengan kriteria tidak dilaksanakan sebanyak 4 orang (12,5\%) dan dilaksanakan sebanyak 17 orang (53,1\%). Berdasarkan hasil uji Chi square di dapatkan hasil $p$ value 0,012, terdapat hubunganantara Sikap responden dengan pelaksanaan Tindakan Pencegahan Resiko Jatuh Pasien.

\section{c. Hubungan Motivasi dengan pelaksanaan Tindakan Pencegahan Resiko Jatuh Pasien}

Berdasarkan penelitian diperoleh hasil analisa bahwa responden dengan motivasi kurang sebanyak 15 orang $(46,9 \%)$ dengan pelaksanaan resiko jatuh dengan kriteria tidak dilaksanakan sebanyak 9 orang $(28,1 \%)$ dan dilaksanakan sebanyak 6 orang $(18,8 \%)$ dan responden dengan motivasi baik sebanyak 17 orang $(53,1 \%)$ dengan pelaksanaan resiko jatuh dengan kriteria tidak dilaksanakan sebanyak 2 orang $(6,3 \%)$ dan dilaksanakan sebanyak 15 orang (46,9\%).Berdasarkan hasil uji Chi square di dapatkan hasil p value 0,004, terdapat hubungan antara motivasi responden dengan pelaksanaan Tindakan Pencegahan Resiko Jatuh Pasien.

\section{SIMPULAN DAN SARAN}

\section{SIMPULAN}

a. Berdasarkan hasil uji Chi square di dapatkan hasil $p$ value 0,000 , terdapat hubungan antara pengetahuan responden dengan pelaksanaan Tindakan Pencegahan Resiko Jatuh Pasien. 
b. Berdasarkan hasil uji Chi square di dapatkan hasil $p$ value 0,012 , terdapat hubungan antara Sikap responden dengan pelaksanaan Tindakan Pencegahan Resiko Jatuh Pasien.

c. Berdasarkan hasil uji Chi square di dapatkan hasil $\mathrm{p}$ value 0,004 , terdapat hubungan antara motivasi responden dengan pelaksanaan Tindakan Pencegahan Resiko Jatuh Pasien.

\section{SARAN}

Meningkatkan motivasi pasien dalam mencegah resiko jantung

\section{UCAPAN TERIMAKASIH}

1. Prof.Dr.Fadil Oenzil,PhD.Sp.GK selaku Ketua Stikes Awalbros Batam;

2. Ibu Ns.Sri Muharni,S.Kep.,M.Kep selaku Ka. Prodi Sarjana Keperawatan Stikes Awalbros Batam

3. IbuNs.Siska Natalia,MSN,Palliative Care selaku pembimbing I

4. Ibu Rizki Sari Utami, Ners,M.Kep selaku pembimbing II.

5. dr.Suryadi selaku direktur RSUD Encik Mariyam Daik Lingga

6. Seluruh Dosen Pengajar yang sudah mendukung proses penyusunan skripsi ini dari awal hingg akhir.7.Seluruh Mahasiswa Sarjana Keperawatan Angkatan XI Stikes Awalbros

\section{DAFTAR RUJUKAN}

Keputusan Menteri Kesehatan Republik Indonesia. (2017). Pusat Data dan Informasi Kemenkes RI, Situasi Tenaga Keperawatan Indonesia. Badan Pemberdayaan Sumber Daya Manusia Kesehatan. Diakses dari http://bppsdmk.kemkes. go.id.

Notoatmodjo, S. (2014). Metodologi Penelitian Kesehatan. Jakarta: Rineka CiptaNotatmodjo. Promosi Kesehatan dan Ilmu Perilaku. Jakarta : Rineka Cipta

Nursalam.(2016). Manajemen Keperawatan Aplikasi Dalam Praktik Keperawatan Profesional Edisi 3. Jakarta: Salemba Medika.

Palomar Health. (2016.) Fall Prevention And Management Patient Safety. n.d. Diakses pada 10 Desember 2019 dari World Health Organization 
website: http://www.who.int/topics/patient_safety/en/.Permenkes tahun 1691/VIII/2011.

Riesenberg, A, L., Leitzsch, J., \& Cunningham, M. (2010). Nursing handoffs :A systemic review of the literature : surprisingly little is known about what constitutes best practice. American Journal of Nursing, 110(4), 2434 .

Sanjoto, H. A. (2014.) Pencegahan Pasien Jatuh Sebagai Strategi Keselamatan Pasien : Sebuah Sistematik Review

Severo, I.M. (2014). Risk Factors for Falls in Hospitalized Adult Patients:an Integrative review.,Rev E8c Enferm USP 2014; 48(3); 537-51.

Sugiyono, P. D. (2015). Populasi dan sampel. Metode Penelitian Kuantitatif, Kualitatif Dan R\&D.

Syam, Y., Noersasongko, D., \& Sunaryo, H. (2015). Fraktur Akibat Osteoporosis. E-CliniC, 2(2). doi.org/10.35790/ecl.2.2.2014.4885

The Joint Commission. (2017). National Patient Safety Goals Effective January 2017. Nursing Care Center Accreditation Program

Underprivileg, A., Motivation, M., Prodigies, I., Children, T., \& Day, P. (2019). November 2019. (November), 16-18.

Widoyoko, Eko. (2016). Teknik Penyusunan Instrumen Penelitian. Yogyakarta: Pustaka Pelajar.

Watson, J, Barbara., et al.2016. The use of the Morse Fall Scale in an Acute Care Hospital, Health \& Rehabilitation Sciences, Westren University, London

Yedavally-Yellayi, S., Ho, A. M., \& Patalinghug, E. M. (2019). Update on Osteoporosis. Primary Care - Clinics in Office Practice, 46(1), 175-190. doi.org/10.1016/j.pop.2018.10.014

Yusup, F. (2018). Uji Validitas dan Reliabilitas Instrumen Penelitian Kuantitatif. Jurnal Tarbiyah: Jurnal Ilmiah Kependidikan. doi.org/10.18592/tarbiyah.v7i1.2100

Ziolkowski, D. (2014). Fall Prevention and Identification of Patients at Risk for Falling, diakses tanggal 10 Desember2019 dari http://www.stjoesonoma. org/documents/Students Instructors/ PVH Fall Prevention. PDF 